http://dx.doi.org/10.5050/KSNVE.2011.21.8.733

$$
\text { 공조용 압축기 배관계의 과도진동 예측 및 저감설계 }
$$

\title{
Prediction and Reduction of Transient Vibration of Piping System for a Rotary Compressor
}

\author{
유 상 모*. 정 의 봉†.한 형 석** \\ Sang Mo Ryu, Weui Bong Jeong and Hyung Suk Han \\ (2011년 5월 24일 접수 ; 2011년 6월 29일 심사완료)
}

Key Words : Rotary Compressor(공조용 압축기), Piping System(배관 시스템), Exciting Force(가진력), Vibration (진동) Time Analysis(시간 해석), Experimental Identification(실험적 규명)

\begin{abstract}
This paper deals with the process to identify the transient exciting force generated from a rotary compressor. The compressor was assumed to be a rigid body. The equation of motion of a rigid compressor supported by three mounts was derived with 6 degree-of-freedom. The exciting forces at the center of mass of the compressor were estimated from the acceleration data measured at compressor shell. Compressor-pipe system was modeled numerically. The accelerations of compressor and pipe were predicted numerically by using the estimated exciting force. A new shape of pipe model was proposed to reduce the vibration. In the prediction by the method in this paper, the maximum acceleration of the pipe could be reduced by $53.7 \%$ at the steady-state and by $12 \%$ at the transient process. In the real experiments, the maximum acceleration of the pipe was reduced by $54.2 \%$ at steady-state and $14.7 \%$ at the transient process. It was verified that the numerical results showed good agreement with experimental results.
\end{abstract}

\section{1. 서 론}

에어컨 실외기에서 발생하는 진동은 대부분 압축 기에 의한 것이며 압축기의 진동은 연결된 배관의 파손을 야기시키는 원인이 된다. 따라서 압축기로부 터 전달되는 배관진동을 설계단계에서 미리 파악하 여 배관의 파손 여부를 예측하고 진동이 작은 배관 모델을 설계할 필요가 있다. 에어컨 가동 시 발생하 는 압축기 질량중심에서의 가진력을 규명하면 압축 기 시스템에 연결된 배관에서의 진동을 예측 할 수

† 교신저자; 정회원, 부산대학교 기계공학부

E-mail : wbjeong@pusan.ac.kr

Tel : (051)510-2337, Fax : (051)517-3805

* 부산대학교 대학원 기계공학부

** 정회원, 국방기술품질원
있게 된다.

압축기 배관 시스템의 진동문제를 해결하기 위해 서 많은 연구가 이루어지고 있다. $\mathrm{Kim}^{(1)}$ 은 선박용 공기압축기의 진동저감을 위해 동흡진기를 설계하 였다. 하지만 동흡진기의 경우 압축기의 과도상태 진동에는 그다지 효과적이지 못하다. $\mathrm{Jeon}^{(2)}$ 은 선형 압축기를 지지하는 지지스프링의 강성을 줄임으로 써 압축기 진동레벨의 저감을 확인 하였다. $\mathrm{Ryu}^{(3)}$ 는 공조용 압축기를 지지하는 마운트의 강성을 줄 임으로써 압축기 진동레벨의 저감을 확인하였다. 하 지만 주파수 해석을 통한 정상상태에서의 해석 결 과이고 시간해석을 통한 과도상태에서의 진동을 해 석하지는 않았다. 압축기의 진동 외에도 배관설계를 통한 배관진동 예측연구도 이루어지고 있다. $\mathrm{Min}^{(4)}$ 은 근사 최적 설계를 통해 배관의 고유진동수를 예 
측하여 공진회피 기준 이내의 배관 질량감소를 제 안하였다. $\mathrm{Kim}^{(5)}$ 은 진동해석 프로그램을 구축하여 진동특성을 고려한 배관설계 시스템을 구축하였다. $\mathrm{Kim}^{(6)}$ 은 공조용 압축기의 가동부분의 운동을 해석 하여 가진력을 규명하였다. 하지만 이는 그 접근법 이 상당히 복잡하고 과도상태의 가진력을 구하기에 는 부적합하다. $\mathrm{Lee}^{(7)}$ 는 압축기 시스템의 운동방정 식을 이용하여 정상상태에서 압축기 질량중심에서 의 주파수 영역 가진력을 구하고 배관에서의 주파 수 응답을 예측하였다.

이 논문에서는 강체로 가정한 압축기의 운동방정 식을 이용하여 압축기 셸에서 측정된 가속도로부터 압축기의 가진력을 예측하는 방안을 제시하고자 한 다. 그리고 양산모델의 압축기에 대하여 시동 직후 의 과도상태부터 정상상태로 수렴하기까지 압축기 에서 발생하는 가진력을 시간영역에서 예측하고자 한다. 배관 응답에 대한 6 방향 가진력의 기여도를 조사 하였으며 규명된 가진력을 이용한 시간 해석 을 통해 배관에서의 진동을 예측한 후 실험으로 얻 은 배관에서의 진동과 비교하여 규명된 가진력의 타당성을 확인하고자 한다. 또한 진동 저감을 위한 새로운 배관형상을 제시하고 실험으로 검증하고자 한다.

\section{2. 이 론}

\section{1 강체 압축기의 모델링}

압축기는 압축기 내부 모터의 회전 주파수와 그 하모닉 성분에서 가장 큰 진동을 일으킨다. 모터 회 전 주파수는 $50 \mathrm{~Hz}$ 의 낮은 주파수이며 이 영역에서 의 압축기는 강체로 가정할 수 있다. 따라서 마운트 가 부착된 강체 압축기는 3 방향의 병진운동과 3 방향 의 회전운동으로 가정 할 수 있으며 Fig. 1 과 같이

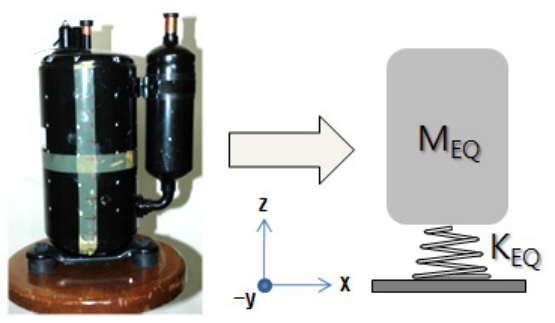

Fig. 1 Idealized model of a compressor
간략하게 모델링 할 수 있다. 압축기 시스템의 좌표 는 Fig. 1 에 정의하였고 사용된 압축기 모델은 QP464P이다.

압축기를 강체로 가정하였으므로 6 자유도를 가지 며 운동에너지는 다음과 같은 2 차 형식으로 나타낼 수 있다.

$$
\begin{aligned}
& \mathrm{K} \cdot \mathrm{E}=\frac{1}{2}\left[\begin{array}{c}
\dot{u}_{G} \\
\dot{v}_{G} \\
\dot{w}_{G}
\end{array}\right]^{T}\left[\begin{array}{ccc}
M_{G} & 0 & 0 \\
0 & M_{G} & 0 \\
0 & 0 & M_{G}
\end{array}\right]\left[\begin{array}{c}
\dot{u}_{G} \\
\dot{v}_{G} \\
\dot{w}_{G}
\end{array}\right] \\
& +\frac{1}{2}\left[\begin{array}{c}
\dot{\theta_{G x}} \\
\dot{\theta_{G y}} \\
\dot{\theta_{G z}}
\end{array}\right]^{T}\left[\begin{array}{ccc}
I_{G x x} & -I_{G x y}-I_{G x z} \\
-I_{G x y} & I_{G y y} & -I_{G y z} \\
-I_{G x z} & -I_{G y z} & I_{G z z}
\end{array}\right]_{G}\left[\begin{array}{c}
\dot{\theta_{G x}} \\
\dot{\theta_{G y}} \\
\dot{\theta_{G z}}
\end{array}\right]
\end{aligned}
$$

여기서 $M_{G}$ 는 압축기 질량이고, $I_{x x}, I_{y y}, I_{z z}$ 와 $I_{x y}$, $I_{x z}, I_{y z}$ 는 압축기 질량중심에서의 각 방향 별 질량관 성모멘트와 질량관성상승모멘트이다. 그리고 $\dot{u}_{G}, \dot{v}_{G}$, $\dot{w}_{G}$ 는 압축기 질량중심에서의 3 방향 병진속도이고, $\dot{\theta_{G x}}, \dot{\theta_{G y}}, \dot{\theta_{G z}}$ 는 3 방향 회전 각속도 성분이다. 그리 고 압축기를 강체로 가정하면 압축기 임의점 $\left(x_{i}, y_{i}, z_{i}\right)$ 에서의 병진 변위벡터 $\{X\}_{i}$ 와 압축기 질량 중심 $\left(x_{G}, y_{G}, z_{G}\right)$ 에서의 변위벡터 $\{X\}_{G}$ 사이에는 다 음의 변환관계가 성립한다.

$$
\{X\}_{i}=\left[T_{i}\right]\{X\}_{G}
$$

단,

$$
\begin{aligned}
& \{X\}_{i}^{T}=\left[u_{i} v_{i} w_{i}\right] \\
& \{X\}_{G}^{T}=\left[u_{G} v_{G} w_{G} \theta_{G x} \theta_{G y} \theta_{G z}\right]
\end{aligned}
$$

여기서 $\left[T_{i}\right]$ 행렬은 임의점의 위치좌표 $\left(x_{i}, y_{i}, z_{i}\right)$ 와 압축기 질량중심좌표 $\left(x_{G}, y_{G}, z_{G}\right)$ 와의 상대좌표로 구해지며 다음과 같다.

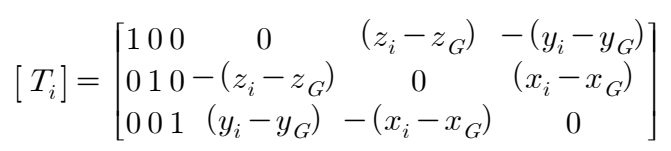

한편, 강체운동을 하는 압축기에서의 위치에너지는 압축기를 지지하는 3 개의 마운트에서 발생한다. $i$ 번째 마운트의 강성의 3 축 방향 성분을 $\left(k_{x i}, k_{y i}, k_{z i}\right)$ 라고 
하면 압축기 질량중심에서의 위치에너지는 다음과 같다.

$$
\begin{aligned}
\mathrm{P} \cdot \mathrm{E}= & \sum_{i=1}^{3} \frac{1}{2}\{X\}_{i}^{T}\left[\begin{array}{ccc}
k_{x i} & 0 & 0 \\
0 & k_{y i} & 0 \\
0 & 0 & k_{z i}
\end{array}\right]\{X\}_{i} \\
& =\sum_{i=1}^{3} \frac{1}{2}\{X\}_{G}^{T}\left[T_{i}\right]^{T}\left[\begin{array}{ccc}
k_{x i} & 0 & 0 \\
0 & k_{y i} & 0 \\
0 & 0 & k_{z i}
\end{array}\right]\left[T_{i}\right]\{X\}_{G}
\end{aligned}
$$

식(1)의 운동에너지와 식(6)의 위치 에너지를 Lagrange 방정식에 대입하면 다음과 같은 운동방정 식이 구해진다.

$$
[M]_{G}\{\ddot{X}(t)\}_{G}+[K]_{G}\{X(t)\}_{G}=\{F(t)\}_{G}
$$

단,

$$
\{F\}_{G}^{T}=\left[F_{G x} F_{G y} F_{G z} M_{G x} M_{G y} M_{G z}\right]
$$

여기서 $\{F\}_{G}$ 는 압축기 질량중심에서 발생하는 각 방향 별 등가힘과 등가모멘트를 나타낸다. 식 (7)의 관성행렬은 식 (1)을 이루는 요소와 동일하며 다음 과 같다.

$$
[M]_{G}=\left[\begin{array}{cccccc}
M_{G} & 0 & 0 & 0 & 0 & 0 \\
0 & M_{G} & 0 & 0 & 0 & 0 \\
0 & 0 & M_{G} & 0 & 0 & 0 \\
0 & 0 & 0 & I_{G x x} & -I_{G x y}-I_{G x z} \\
0 & 0 & 0 & -I_{G x y} & I_{G y y}-I_{G y z} \\
0 & 0 & 0 & -I_{G x z}-I_{G y z} & I_{G z z}
\end{array}\right]
$$

마찬가지로 식 (7)의 강성행렬은 식 (6)을 이루는 요소와 동일하며 다음과 같다.

$$
[K]_{G}=\sum_{i=1}^{3}\left[T_{i}\right]^{T} \operatorname{diag}\left(k_{x i}, k_{y i}, k_{z i}\right)\left[T_{i}\right]
$$

\section{2 압축기 가진력의 추정 이론}

압축기 질량중심좌표에 대한 운동방정식인 식 (7) 의 우변항인 가진력 $\{F(t)\}_{G}$ 를 추정할 필요가 있 다. 압축기 셸 표면 여러 점에서 발생하는 가속도 $\{\ddot{X}\}_{P}\left(\mathrm{p}=1 \sim \mathrm{N}_{\mathrm{p}}\right)$ 를 측정하여 질량중심점에서 발생하 는 가진력 $\{F(t)\}_{G}$ 를 추정한다. $\{\ddot{X}\}_{P}$ 와 압축기 질 량중심에서 병진 및 회전방향 가속도 $\{\ddot{X}\}_{G}$ 는 식
(2)와 마찬가지로 다음과 같은 관계를 가진다.

$$
\{\ddot{X}(f)\}_{P}=\left[T_{P}\right]\{\ddot{X}(f)\}_{G}
$$

단,

$$
\begin{aligned}
& \{\ddot{X}(f)\}_{P}=[\ddot{u}, \ddot{v}, \ddot{w}]^{T} \\
& \{\ddot{X}(f)\}_{G}=\left[\ddot{u}_{G}, \ddot{v_{G}}, \ddot{w}_{G}, \ddot{\theta}_{x}, \ddot{\theta}_{y}, \ddot{\theta}_{z}\right]^{T}
\end{aligned}
$$

여기서 $[T]_{P}$ 는 식 (5)와 마찬가지로 다음과 같이 정 의 된다.

$$
\begin{aligned}
& {\left[T_{P}\right]}
\end{aligned}
$$

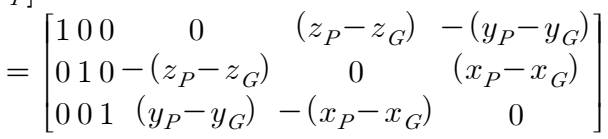

식 (11)에 주어진 좌변과 우변의 오차제곱의 합은 다음과 같이 나타낼 수 있다.

$$
J=\left\|\{\ddot{X}(f)\}_{P}-\left[T_{P}\right]\{\ddot{X}(f)\}_{G}\right\|^{2}
$$

셸 표면에서 측정된 가속도 채널 수 $N_{P}$ 를 6 보다 크게 설정하면 최소자승법을 이용하여 식(15)에 주 어진 오차제곱의 합이 최소가 되도록 압축기 질량 중심에서의 가속도 $\{\ddot{X}\}_{G}$ 를 다음과 같이 추정할 수 있다.

$$
\{\ddot{X}(f)\}_{G}=\left(\left[T_{P}\right]^{T}\left[T_{P}\right]\right)^{-1}\left[T_{P}\right] T\{\ddot{X}(f)\}_{P}
$$

여기서 $\{\ddot{X}\}_{P}$ 는 $N_{P} \times 1$ 벡터가 된다. 식 (8)에서 정의 된 압축기 질량중심에서 발생하는 힘과 모멘트는 식 (7)로부터 다음과 같이 표현할 수 있다.

$$
\{F(f)\}_{G}=\left([M]_{G}-\frac{1}{(2 \pi f)^{2}}[K]_{G}\right)\{\ddot{X}(f)\}_{G}
$$

여기서 $f$ 는 푸리에변환 시 데이터의 주파수성분을 나타낸다.

Fig. 2와 같이 압축기 셸 표면 임의의 3점에서 3 축 가속도계를 이용하여 9 채널의 가속도 $\{\ddot{X}(t)\}_{P}$ 를 측정하고 푸리에변환을 통해 $\{\ddot{X}(f)\}_{P}$ 를 구하였다. 그리고 식 (16)을 이용해 압축기 질량중심에서의 가속 도 $\{\ddot{X}(f)\}_{G}$ 를 추정하였다. 푸리에변환된 데이터의 


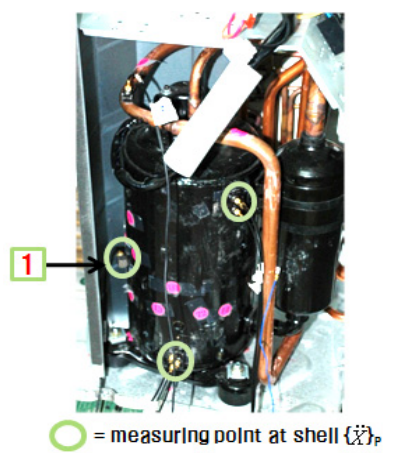

Fig. 2 Measured point at shell

주파수 $f$ 를 변화시켜 가면서 식(17)로부터 가진력 $\{F(f)\}_{G}$ 를 추정하였다. 그리고 다음식과 같이 역 푸리에 변환을 통해 압축기 질량중심점에서의 시간 영역 가진력 $\{F(t)\}_{G}$ 를 구하였다.

$$
\{F(t)\}_{G}=\mathfrak{I}^{-1}\left[\left\{F(f)_{G}\right\}\right]
$$

식 (18)과 같이 $\{F(t)\}_{G}$ 가 추정되면 식 (7)의 운 동방정식으로부터 압축기 질량중심점에서의 변위응 답 $\{X(t)\}_{G}$ 또는 가속도 응답 $\{\ddot{X}(t)\}_{G}$ 를 구할 수 있다. 그리고 식 (2)로부터 압축기 셸 표면에서의 응 답을 예측할 수 있다. 또한 배관을 모델링하면 배관 임의점 응답도 예측할 수 있다.

\section{3. 실험적 규명}

\section{1 압축기 가진력의 규명}

Fig. 2는 압축기 셸에서의 가속도 측정 모습이다. 3 점 각각의 3 방향인 총 9 채널의 가속도를 측정하였 으며, $\mathrm{B} \& \mathrm{~K}$ 사의 charge타입 3축 가속도 센서를 사 용하였다. Fig. 3은 Fig. 2의 1번 위치에서의 가속도 실험데이터이다. 여기서 a)는 압축기 셸의 접선방향 가속도이고 $\mathrm{b}$ )는 압축기 셸의 수직방향 가속도, c) 는 압축기 셸의 반지름방향 가속도이다. Fig. 3을 보 면 압축기의 주 운동 방향인 압축기 셸의 접선방향 가속도가 가장 큰 것을 확인 할 수 있다. Fig. 4 및 Fig. 5는 이 연구에서 제시한 방법으로 추정한 압축 기 질량 중심에서 발생하는 힘 및 모멘트 결과이다. 그래프를 살펴보면 에어컨의 시동 후 압축기 질량 중심에서의 가진력이 크게 증가하였다가 정상상태 로 수렴하는 것을 알 수 있다. 이는 압축기의 회전

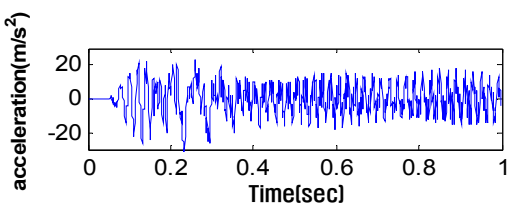

(a) Tangential component

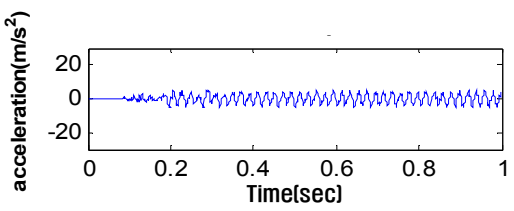

(b) Vertical component

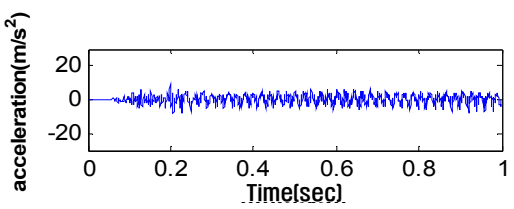

(c) Radial component

Fig. 3 measured data of acceleration at shell

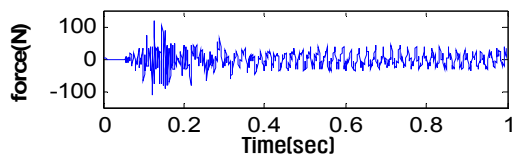

(a) x-component

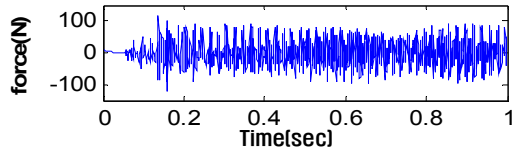

(b) y-component

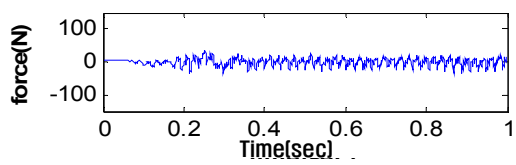

(c) z-component

Fig. 4 Identified signal of exciting force

주파수가 정상상태 회전주파수인 $50 \mathrm{~Hz}$ 까지 점차 증가하면서 압축기의 고유진동수를 통과할 때 발생 하는 공진현상에 의한 것으로 추정된다. Fig. 4 의 가 진력의 병진방향 성분을 살펴보면 압축기의 거동은 실린더의 회전에 의해 일어나기 때문에 수평방향의 $\mathrm{x}, \mathrm{y}$ 축 가진력에 비해 수직방향인 $\mathrm{z}$ 축 가진력이 상대 적으로 작은 것을 알 수 있다. 또한 실린더의 회전에 의한 압축기 거동특성에 의해 Fig. 5 의 $\mathrm{Z}$ 축 모멘트 


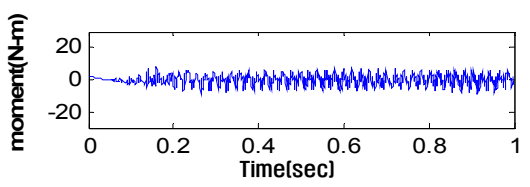

(a) x-component

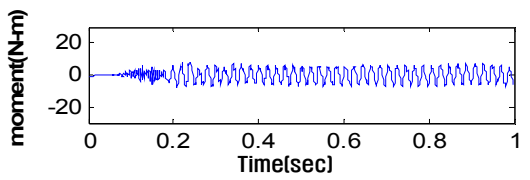

(b) y-component

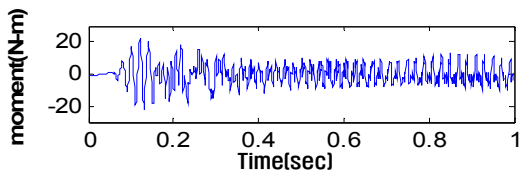

(c) z-component

Fig. 5 Identified signal of exciting moment

가진력이 다른 두 방향의 모멘트 가진력보다 상대 적으로 큰 것을 알 수 있다.

\section{2 가진력의 검증}

압축기-배관 시스템의 진동을 예측하기 위해 범 용 모델링 소프트웨어 Patran을 이용하여 Fig. 6과 같이 기존의 양산모델과 동일한 형상의 파이프 모 델을 만든 후 압축기 질량중심위치에 압축기 질량 및 질량관성모멘트 정보를 입력하였다. 압축기 질량 중심위치와 연결되는 배관 위치 및 마운트 위치를 $\mathrm{MPC}$ (multi point constraint)기법 중 하나인 RBE2 (rigid body element, form2)로 연결시킨다. RBE2 로 연결시킴으로써 압축기 질량중심위치와 연결되 는 배관 위치가 강체로 연결된 효과를 가질 수 있 다. 마운트 부위에는 병진 3 방향으로 스프링효과를 준 후 그 끝을 고정시켜 실제 마운트와 유사한 효 과를 재현하였다.

추정된 가진력의 타당성을 검증하기 위해 Fig. 7(a) 의 압축기 시스템 전산모델의 질량중심에 $\{F(t)\}_{G}$ 를 입력하고 범용 소프트웨어인 NASTRAN의 과도응답 해석(SOL:112)을 이용하여 Fig. 7의 $\square$ 위치에서의 배관진동을 예측하고 같은 지점의 측정값과 비교하 였다. Fig. 8은 예측값과 실험값의 비교 그래프이다. 실선은 예측값이고 $\boldsymbol{\square}$ 는 실험값이다. 그래프를 살펴 보면 압축기가 가동되면서 가속도가 크게 나타나는 과도상태를 지나다가 점차 가속도가 안정되는 정상

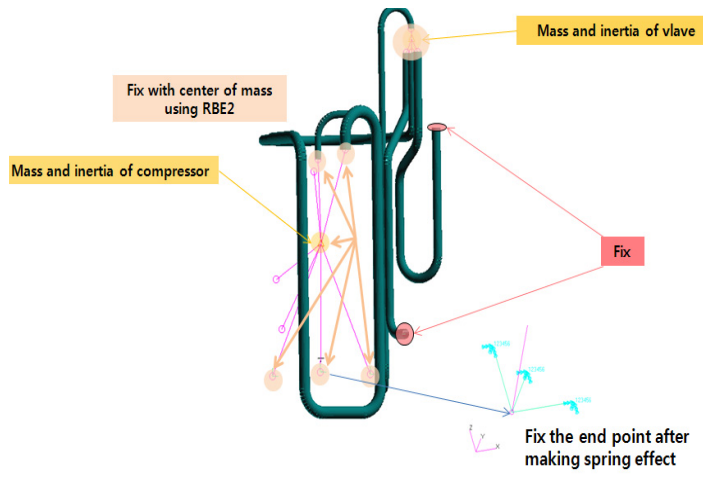

Fig. 6 Define the numerical model

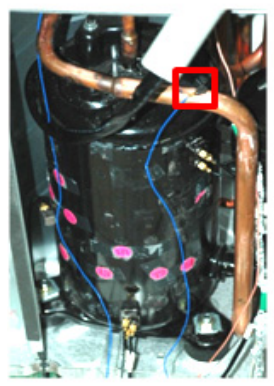

(a) Real model

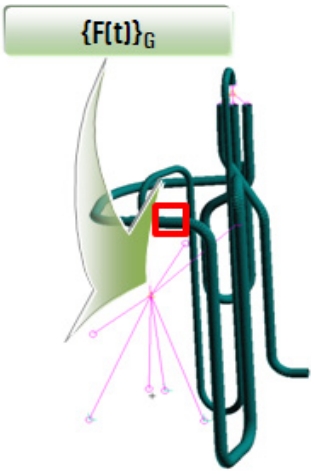

(b) Numerical model
Fig. 7 Compressor-pipe model

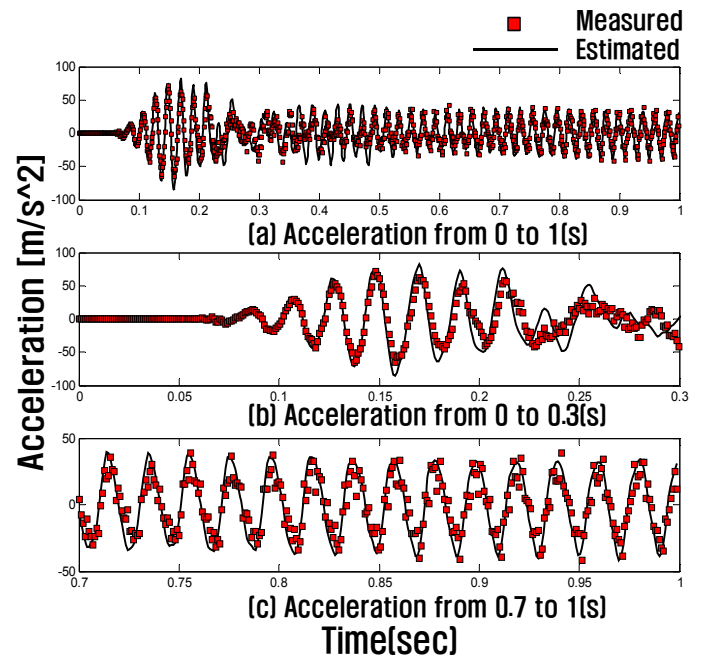

Fig. 8 Comparison of pipe acceleration

상태로 접어드는 것을 볼 수 있다. (b)는 0 초부터 0.3 초까지 과도상태에서의 그래프 확대영역이고 (c)는 


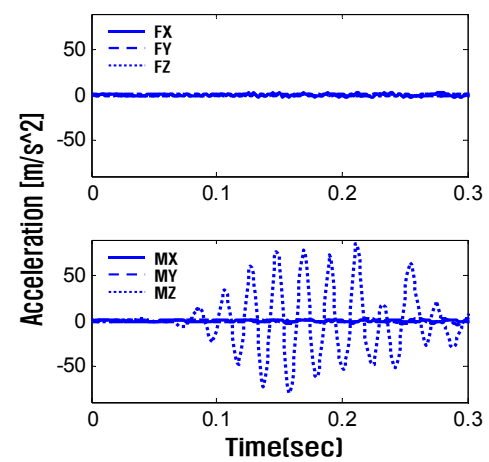

Fig. 9 Pipe acceleration according to each exciting force

0.7 에서 1 초까지 정상상태에서의 그래프 확대영역 이다. 과도상태와 정상상태에서 예측결과는 실험결 과와 비교적 일치하므로 이 연구에서 추정한 가진 력 및 전산 모델링이 타당하다고 볼 수 있다.

\section{3 배관 응답에 대한 가진력의 기여도}

전산 모델에 6 방향 가진력중 각각 한방향의 가진 력만을 입력하고 시간해석을 통해 배관응답을 살펴 보았다. Fig. 9는 Fig. $7 \square$ 위치에서의 각각 방향 가 진력에 대한 가속도 결과이다. 다른 5 방향 가진력에 비해 $\mathrm{z}$ 방향 모멘트 $\mathrm{Mz}$ 에 의한 가진력이 배관 응답 의 대부분에 기여를 하는 것을 알 수 있다.

\section{4. 배관 형상의 변경설계}

\section{1 진동저감 배관 형상}

배관진동 저감을 위하여 다양한 배관형상을 모델 링 하였으며 최종적으로 Fig. 10(b)와 같은 배관을 선정하였다.

\section{2 주파수 응답함수의 비교}

$\mathrm{Z}$ 방향 모멘트 $\mathrm{Mz}$ 에 대한 Fig. 10 각각의 배관 $\bigcirc$ 위치의 주파수 응답함수를 전산을 통해 구하였다. $\bigcirc$ 위치는 에어컨 작동 중 최대진동을 일으키는 위 치이다. Fig. 11은 두 배관의 주파수 응답함수를 비 교한 그래프이다.

Fig. 11의 $50 \mathrm{~Hz}$ 이하영역에서 주파수 응답함수를 보면 기존 배관 형상에 비해 변경된 배관 형상의 크 기가 더 작은 것을 알 수 있다. 따라서 압축기의 회 전주파수가 정지 상태에서 작동주파수인 $50 \mathrm{~Hz}$ 까지

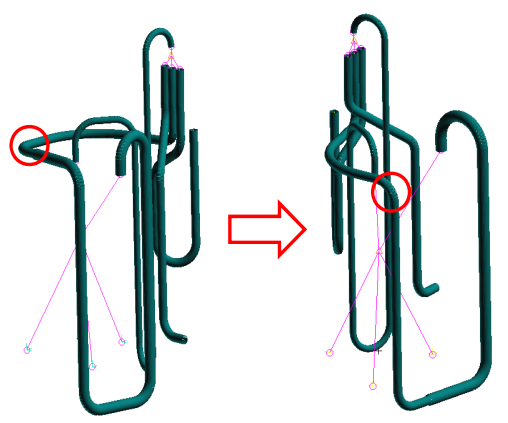

(a) Conventional model (b) Proposed model

Fig. 10 Numerical model of pipe system

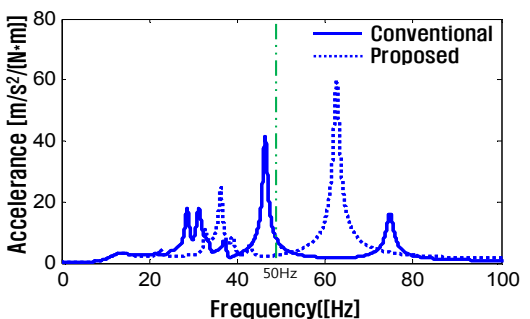

Fig. 11 Comparison of FRF

증가하는 과도상태에서의 진동크기가 기존의 배관에 비해 변경된 배관이 더 낮을 것이라 예측할 수 있다. 또한 압축기 시스템 작동주파수인 $50 \mathrm{~Hz}$ 근처에서의 주파수 응답함수를 살펴보면 기존의 배관은 공진점 이 $50 \mathrm{~Hz}$ 부근에 있는 반면 변경된 배관은 $50 \mathrm{~Hz}$ 에서 멀리 떨어져 있으므로 정상상태에서의 진동 역시 변 경된 배관에서 더 낮을 것이라 예상된다.

\section{3 정상상태 배관진동의 예측 및 실험}

앞 절에서 구한 가진력의 정상상태 신호를 전산 모델에 입력하고 해석하였다. Fig. 12는 Fig. 10의 $\bigcirc$ 위치 가속도응답 해석결과이며 $\mathrm{y}$ 축은 3 방향 가속 도의 크기로 $\sqrt{a_{x}^{2}+a_{y}^{2}+a_{z}^{2}}$ 을 나타낸다.

이 연구에서 제시한 배관형상은 기존 배관형상에 비하여 압축기 작동주파수 $(50 \mathrm{~Hz})$ 에서의 가속도가 $31.78 \mathrm{~m} / \mathrm{s}^{2}$ 에서 $14.71 \mathrm{~m} / \mathrm{s}^{2}$ 로 약 $53.7 \%$ 가 줄어드는 것으로 예측되었다. 그리고 해석결과의 타당성을 검 증하기 위해 Fig. 13과 같이 실제 배관을 제작하고 실험을 수행하였다. 전산해석과 마찬가지로 최대진 동을 일으키는 배관위치에서의 가속도를 측정하여 비교하였다. Fig. 14는 Fig. 13의 $\bigcirc$ 위치 가속도 응답 


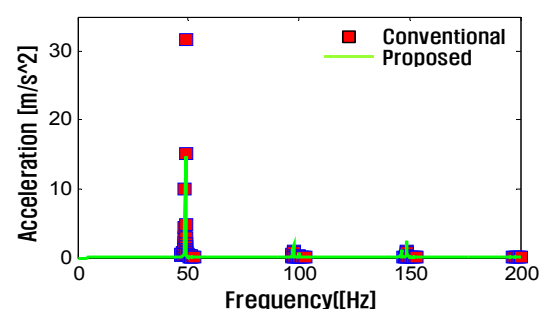

Fig. 12 Estimated acceleration of pipe in steady-state

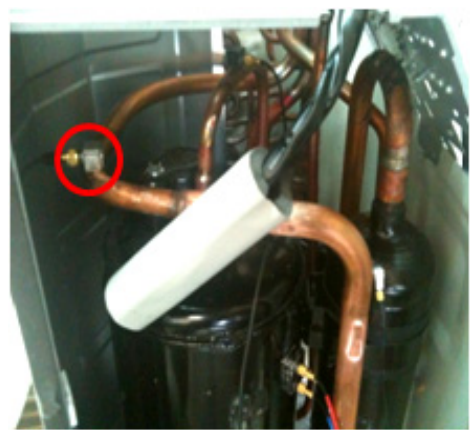

(a) Conventional model

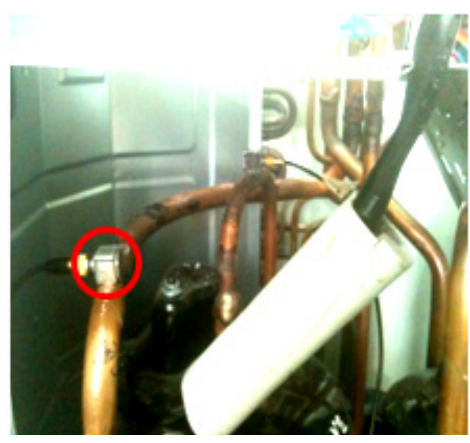

(b) Proposed model

Fig. 13 Real pipe systems

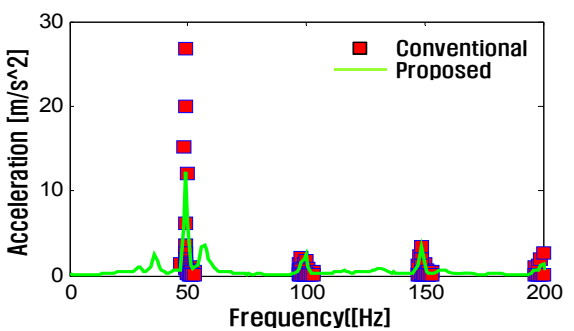

Fig. 14 Measured acceleration of pipe in steady-state 측정결과이다.

배관의 형상 변경에 따라 압축기 작동주파수 $(50$ $\mathrm{Hz}$ )에서의 가속도가 $26.75 \mathrm{~m} / \mathrm{s}^{2}$ 에서 $12.24 \mathrm{~m} / \mathrm{s}^{2}$ 로

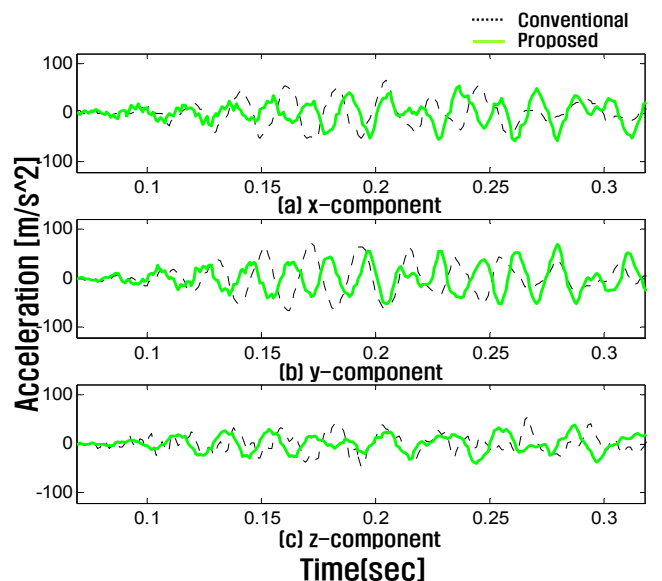

Fig. 15 Estimation of transient acceleration of pipe

Table 1 Estimation of maximum pipe acceleration

\begin{tabular}{c|c|c|c|c}
\hline \hline & $a_{x}$ & $a_{y}$ & $a_{z}$ & $\sqrt{a_{x}^{2}+a_{y}^{2}+a_{z}^{2}}$ \\
\hline $\begin{array}{c}\text { Conventional } \\
\left(\mathrm{m} / \mathrm{s}^{2}\right)\end{array}$ & 65.2 & 72.5 & 55.8 & 112.3 \\
\hline $\begin{array}{c}\text { Proposed } \\
\left(\mathrm{m} / \mathrm{s}^{2}\right)\end{array}$ & 60.0 & 68.0 & 39.5 & 98.8 \\
\hline
\end{tabular}

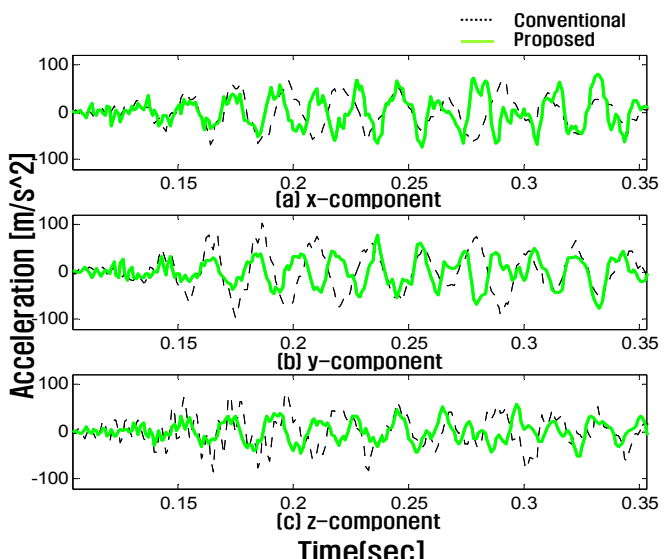

Fig. 16 Measured transient acceleration of pipe

Table 2 Measured maximum pipe acceleration

\begin{tabular}{c|c|c|c|c}
\hline \hline & $a_{x}$ & $a_{y}$ & $a_{z}$ & $\sqrt{a_{x}^{2}+a_{y}^{2}+a_{z}^{2}}$ \\
\hline $\begin{array}{c}\text { Conventional } \\
\left(\mathrm{m} / \mathrm{s}^{2}\right)\end{array}$ & 67.7 & 101.8 & 81.0 & 146.6 \\
\hline $\begin{array}{c}\text { Proposed } \\
\left(\mathrm{m} / \mathrm{s}^{2}\right)\end{array}$ & 79.8 & 77.6 & 57.1 & 125.1 \\
\hline
\end{tabular}

약 $54.2 \%$ 가 줄어드는 것을 확인 할 수 있었고 하 모닉성분 $(100 \mathrm{~Hz}, 150 \mathrm{~Hz})$ 에서는 큰 차이가 없었다. 
측정결과가 예측결과와 유사한 경향을 나타냄을 알 수 있으며 이 연구에서 제시하는 방법의 타당성을 확인할 수 있다.

\section{4 과도상태 배관진동의 예측 및 실험}

과도상태 영역에서의 가진력을 전산 모델에 입력 하고 해석하였다. Fig. 15는 Fig. 10의 $\bigcirc$ 위치 가속 도 응답 해석 후 과도영역 시간데이터를 비교한 그 래프이며, Table 1은 Fig. 15의 각 방향 별 최대 가 속도 값을 비교한 결과이다. 기존의 배관에서의 최 대 가속도 크기는 $112.3 \mathrm{~m} / \mathrm{s}^{2}$ 이지만 설계 변경된 배 관에서의 최대 가속도 크기는 $98.8 \mathrm{~m} / \mathrm{s}^{2}$ 으로 약 $12.0 \%$ 감소하는 것으로 예측되었다.

설계 변경 전 배관모델과 설계 변경 후 배관모델 을 제작하고 가속도를 실험을 통해 측정하였다. Fig. 16은 Fig. 10 의 $\bigcirc$ 위치 과도영역 실험데이터를 비교 한 결과이다. Table 2는 Fig. 16의 각 방향 별 최대 가속도 값의 비교 결과이다. 설계 변경에 따라 최대 가속도 값이 $146.6 \mathrm{~m} / \mathrm{s}^{2}$ 에서 $125.1 \mathrm{~m} / \mathrm{s}^{2}$ 으로 약 14.7 $\%$ 감소되는 것을 확인하였으며 예측결과와 비슷한 경향을 나타냄을 확인하였다.

\section{5. 결 론}

(1) 압축기 셸에서의 가속도 데이터로부터 압축 기 질량중심점에서의 정상상태 및 과도상태 가진력 을 시간영역에서 추정하는 방안을 제시하였다.

(2) 추정된 가진력을 압축기 시스템의 전산 모델 에 입력하고 해석하여 정상상태 및 과도상태에서의 배관진동을 예측하였으며 실험결과와 비교함으로써 타당성을 검증하였다.

(3) 이 연구에서 제시한 방법을 이용하여 새로운 배관형상을 제시하였다. 기존의 양산모델의 배관형 상에 비하여 정상상태에서 가속도가 $53.7 \%$ 저감되 고, 과도상태에서는 가속도가 $12.0 \%$ 저감되는 것 으로 예측되었다.

(4) 새로운 형상의 배관과 기존형상의 배관을 제 작하여 가속도를 측정한 결과 최대 가속도 발생위 치에서 정상상태에서는 가속도가 $54.2 \%$ 저감되고 과도상태에서는 가속도가 $14.7 \%$ 저감되었으며 예 측결과와 비슷한 경향을 나타내었다.

\section{참 고 문 헌}

(1) Kim, H. J., Hwang, S. J. and Jim, U. K., 2006, Vibration Reduction of Marine Air Compressor Using Dynamic Vibration Absorber, Journal of the Korean Society of Marine Engineering First Conference, pp. 35 36.

(2) Jeon, S. H., Jeong, W. B., Won, S. G. and Lee, H. J., 2007, Design of Connecting Part of Linear Compressor to Reduce the Vibration Level of $60 \mathrm{~Hz}$, Proceedings of the KSNVE Annual Autumn Conference, pp. 1360 1365.

(3) Ryu, S. M., Jeong, W. B., Han, H. S. and Ahn, J. W., 2010, Optimal Design of Mount for Vibration Reduction of an Rotary Compressor, Proceedings of the KSNVE Annual Spring Conference, pp. 142 143.

(4) Min, J. H., Choi, D. H. and Jung, D. H., 2009, Shape Optimization of an Air Conditioner Piping System, Transactions of the Korean Society for Noise and Vibration Engineering, Vol. 19, No. 11, pp. 1151 1157.

(5) Kim, J. H., Park, C. B., Choi, S. Y. and Min, J. H., 2004, Optimal Design of Pipe Configuration of an Air Conditioner Outdoor Unit Considering Vibration Characteristics, Transactions of the Korean Society of Mechanical Engineering Annual Autumn Conference, pp. 655 660.

(6) Kim, J. H., Jeong, W. B., Hwang, S. W. and Ahn, S. J., 2002, Analysis of Transient Response of Airconditing Rotary Compressors Considering the Coupled Effect of Motor, Transactions of the Korean Society for Noise and Vibration Engineering, Vol. 12, No. 11, pp. 847 885.

(7) Lee, H. W., Ryu, S. M., Jeong, W. B., Han, H. S., Ahn, J. W. and Jeong, S. W., 2010, Force Identification of a Rotary Compressor and Prediction of Vibration on a Pipe, Transactions of the Korean Society for Noise and Vibration Engineering, Vol. 20, No. 10, pp. 953 959. 